\title{
Gastronomy Tourism Attraction in Ternate City
}

\author{
Turgarini, Dewi \\ Tourism Studies Doctoral Programme \\ Universitas Gadjah Mada \\ Yogyakarta, Indonesia \\ dewiturgarini@gmail.com
}

\author{
Pridia Rukmini Sari, Heni \\ Hospitality and Tourism Departement \\ Sekolah Tinggi Administrasi Mandala Indonesia \\ Jakarta, Indonesia \\ heni.pridia@yahoo.com
}

\begin{abstract}
Indonesia has a target of tourist arrivals in 2019, a total of 20 million tourists to visit. Ternate City is the one of government target to increase tourist visitation. They saw that this city has a a variety of tourism products especially the gastronomy who was known influences spice in Europe since 1510. This study was designed to find Ternate featured gastronomy that deserves to become gastronomy tourism destination. The approach used in this study is a descriptive exploratory study, contain description of the data in tabular form and narrative facts corresponding field. The primary data obtained from interviews, observations and focus groups involving all tourism stakeholders. The results obtained showed that Ternate has a varied potential gastronomy with very full featured. This city has potential gastronomy which is presented for ceremonial purposes that have not been commercialized. The people of Ternate saw five menu that can be used as icon and attraction such as Papeda, Gohu Fish, Fufu Smoked Fish, Soru Fish Soup, Garu Vegetable. The promotions and strategies to educate travelers about the gastronomy profile need to be done to make the maximum of the Ternate featured foods familiar to tourists.
\end{abstract}

\section{Keywords - Gastronomy, familiarization and educated}

\section{INTRODUCTION}

UNWTO (2015) Tourism Highlights 2015 predicts the presence of international travelers growth between $3-4 \%$. This is in line with the long-term forecast that the growth of Tourism in 2030 will be reach $3.3 \%$ per year. For 2015, Asia and the Pacific and America became the strongest region for international tourist arrivals (grow 4-5\%), followed by Europe $(+3-4 \%)$, Middle East (+2-5\%) and Africa (+3-5\%).

According to UNWTO (2012) and Ministry of Tourism of Republik Indonesia (2015), the situation showed that about $30 \%$ of global tourism revenue comes from tourism gastronomic tours, $40 \%$ of tourist expenditure is food and drinks, and $50 \%$ of revenue comes from the restaurant rating. Since 2005 many countries in the world to initiate creative cities under the guidance of the United Nations Educational Scientific and Cultural Organization (UNESCO) became the city gastronomy. This is done by the City of Popayan (Colombia), Chengdu and Shunde (China), City Ostersund (Sweden), City of Zahle (Lebanon), City of Jeonju (Korea), City Floriannopolis (Brazil), City Tzuruoka (Japan) and others.
Lifting a town into a city of gastronomy related to cultural tourism, certainly has the potential for widespread benefits not only to the economic sector, but also the social and cultural sectors. Gastronomy (gastronomy) is an art and a science, even appreciation that cuts across tribe, nation, race, group, religion, gender and culture to learn the details of food and beverages for use in a variety of conditions and situations. In the gastronomic own understanding not only focus on the culinary arts alone, but also on human behavior, including how to cook, serve, to taste, feel and experience as well as finding, studying, researching and writing about food and all things related to human nutrition in every nation and state (Soeroso, 2014; Wikipedia, 2014).

Studies are underway to explore the potential of Ternate City with focus attraction of Gastronomic tourism is not without reason. Marco Ramerini in 2008 in the journal entitled "The Spanish Fortresses in Tidore Island from 1521 to 1663, the Moluccas, Indonesia" explained that since 1510 the city has influenced the development of European gastronomy with the spices. Surveys, focus group discussions, and in-depth interviews conducted research team held by writer cooperated with Assistant Deputy Development of Cultural Tourism Culinary and Spa of the Ministry of Tourism of the Republic of Indonesia show that the existence of gastronomic in this town indeed strong in the archipelago. When the digging the potential of gastronomic tourism in the city of Makassar and Ternate, Tidore, and Morotai Island in North Maluku in 2016, there is a finding that the Sultanate of Ternate influence the taste in other parts of the archipelago, especially Makassar City.

\section{1) Tourism and Gastronomy}

According to the International Culinary Tourism and writing

Forming Association (Manolis, 2010), gastronomic tourism is defined as "the pursuit of eating and drinking experience that is unique and easy to remember (the pursuit of unique and memorable eating and drinking experiences)". Gastronomic perspective is used because it is perceived to have a broader spectrum of coverage compared to the culinary. Gastronomy not just focus on the food (food and drink) alone, but also integrate cultural factors and human behavior as supporters ranging from the procurement of food sources, how to process, serving, taste and have the experience of enjoying it, until by searching, studying, researching a city into a 
gastronomic city is not an easy task. UNESCO (2015) states that the city of gastronomic needs to meet the following criteria.

a. The development of skill to good cook as a characteristic of the city center and / or region;

b. The existence of a community which has cook skills, and there are many traditional restaurants and / or chefs;

c. The use of local raw materials traditional cuisine cooking; with local knowledge, traditional culinary practices and methods of cooking that has withstood the industrial or technological advances; availability of traditional food markets and traditional food industry; d. There is a tradition of hosting gastronomic festivals, the awards, contests and means extensive and has other targets that gain recognition nationally and internationally.

e. There is a respect for the environment and promotion of sustainable local products;

f. Have the ability to maintain public appreciation, and there is a promotion of nutrition in educational institutions and inclusion of biodiversity conservation programs in cooking schools curricula.

We also should see the context of the role of food as component of gastronomic tourism. Hall and Mitchell (2001) make up the category based on the motivation and behavior of tourists to enjoy the food and enjoy it.

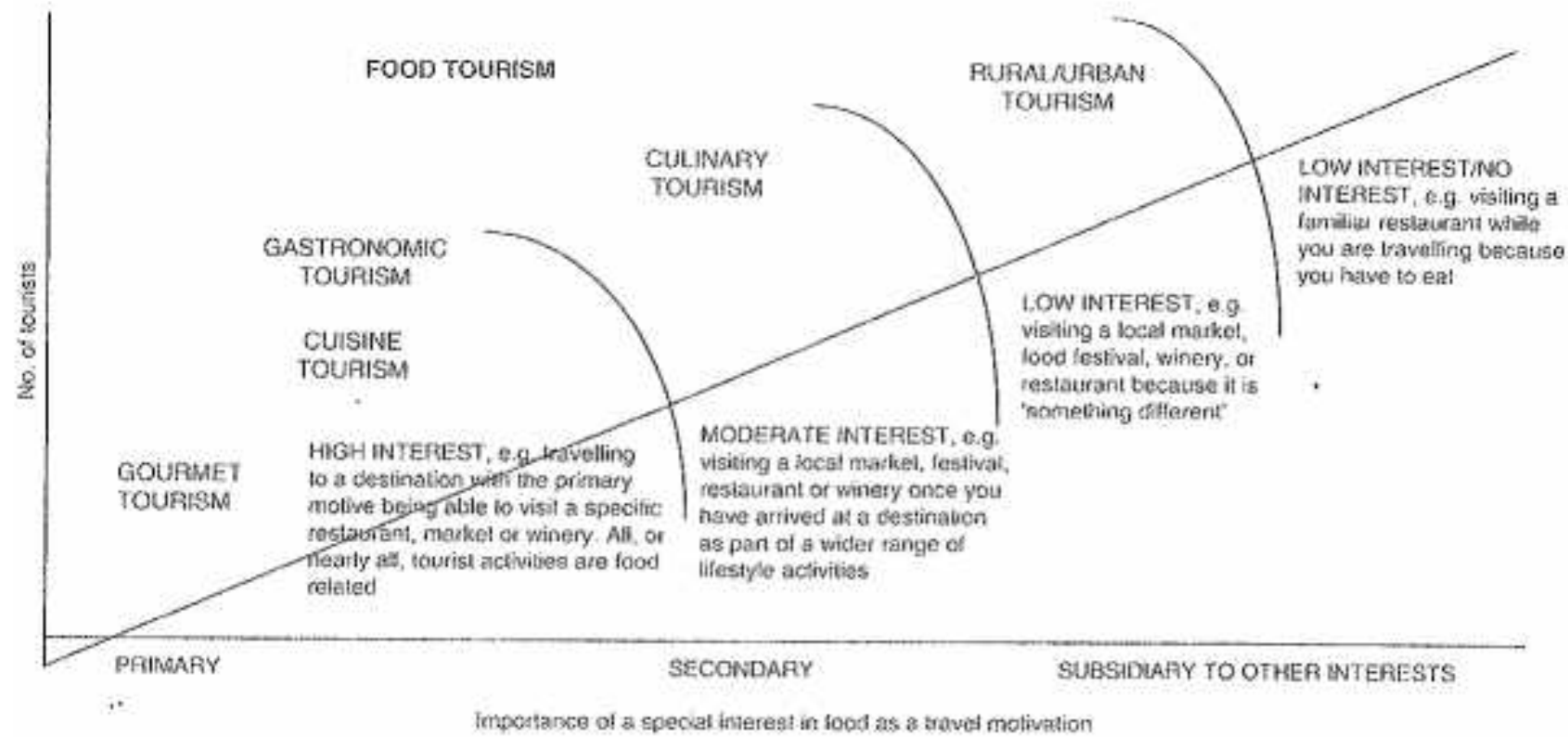

Fig. 1. Categorization Food Tourism based Motivation and Number of tourists

From the picture above Hall and Mitchell wanted to convey that food tourism can categorized using interest rate and the number of tourists visiting tourists. Traveller interest divided into three categories: primary, secondary, and tertiary. Description The categorization is as follows.

a. Gastronomic Tourism, this kind of tourism is done by tourists with a very high motivation to certain foods or beverages in certain areas. It is usually associated with expensive or the 'top end' restaurants, wineries, and festivals. Almost all tourist activities undertaken related to that interest. Gastronomic tourism is divided widened two which is gourmet tourism ${ }^{1}$ and gastronomic tourism ${ }^{2}$.

a) Gourmet is a cultural ideal associated with the culinary arts of fine food and drink, or haute cuisine, which is characterised by refined, even elaborate preparations and presentations of b. Second Subset is culinary tourism, is culinary tours include general foods business as part of a lifestyle like visiting a local festival or market. In this category of food is a secondary motivation for tourists.

c. Third Subset is Urban tourism / rural. It regards tourism type of food as part of the necessities of life. Traveller interest of this type is not the food, but if

aesthetically balanced meals of several contrasting, often quite rich courses.

b) Gastronomic tourism is an experience pursued by visiting and tasting food and beverages at primary or secondary producers', visiting food and beverage festivals and consuming authentic specialties in various restaurants. An increasingly popular form of gastronomic tourism is an activity of tourists who attend diff erent multi-day schools of authentic regional cooking (Hall \& Mitchell, 2006) 
they feel that can not tasty, they are still paying interest.

Consumption of food as gastronomy component turned out to be an integral aspect of the experience traveled, not just a matter of taste and presentation, but also by a sense of enjoying the place. It can almost be said of all to eat. Local food is a fundamental component of the destination attributes, add rich attractions and the overall travel experience (Symons, 1999).

This is what makes food become an important constituent of the production and consumption of tourism. When you see the following

a. Journey in which there is an appreciation and consumed local or regional food.

b. Travel with the main purpose of enjoying food, and drinks as a travel experience or to attend a specific culinary activities such as cooking schools, visit the places of production of food or drink, folk market, or enjoy the food at various places that provide them (taste trail).

\section{c. The unique experience of eating and drinking}

Culinary as part of gastronomy has grown into a market segment, and usually a gastronomic tour is often combined with other activities such as cultural tourism, cycling, walking, etc. As a result, this segment demand by consumers with a wide circle. This then led to the emergence of local food and drink festival, as well as an increased interest in the local market. The growth of this niche market will be strong in the next 5-10 years, albeit from a relatively small base. There are many many regions, and cities in Indonesia which has potential as a gastronomy tourism destination area that can be developed but has not been well managed, and integrated with, so it cannot be recognized and visited by the public. The condition is understood that the need for the development of integrated gastronomy tourism potential between managers, government and society. The roots of these efforts is the urgency to do promotions in introducing gastronomy tourism destinations located in Indonesia on the local population, domestic, and foreign tourists.

In particular, this study aims to determine the level of development of the quality of life in Ternate as gastronomy tourism destination. Some questions about the development of tourism destinations is how to change the quality of life occurred in the region and indeed true that the development of tourism destinations have an impact on changes in quality of life in society. In other words, besides tourism destination development phase is determined by the number of tourists visiting also by the level of quality of life in society. This study wanted to see if increased number of tourists that caused the passing of economic activity has also resulted positive to the level of the quality of life of local communities in development.

Inskeep (1991), suggests some of the components involved in the development of tourism destinations, namely:

a. Tourist attractions, namely tourist activities in question can be all things related with natural environment, the culture, the uniqueness of an area and other activities related to tourism activities that attract tourists to visit a tourist attraction.

b. Accommodation, namely a wide range of hotels and various types of other facilities associated with the service to the tourists who intend to stay overnight during a sightseeing trip they do.

c. Amanitas, namely the various facilities and tourist services in the planning of tourist areas. The amenities include tour and travel operations (also called reception services). Such facilities eg restaurants and various types of other eating places, shops selling handicrafts, souvenirs, specialty stores, grocery stores, banks, exchange point money and care facilities other financial, tourist information office, personal services (such as salon beauty), health care facilities, public safety facilities (including police stations and fire departments), and travel facilities for incoming and outgoing (such as immigration and customs) and so on.

d. Transportation, includes transportation access to and from the tourist areas, internal transport that connects the main attractions of the tourist area and the surrounding region development area, including all types of facilities and services related to land, water, and air.

e. Infrastructure is the provision of clean water, electricity, drainage, sewerage, telecommunications

There is many various definitions put forward as a reference for the preparation of databases gastronomy tourism destination are as follows.

a. Culinary Tourism Destinations is an administrative territorial unit (city) that has one or more local culinary attractions

b. Culinary Attractions is the unity of the geographical area in a city that has one or more local culinary tourism product either restaurants or cafes, food courts, a cottage industry that displays the particular culinary theme and relating to the locality of the region.

c. Products Culinary Tourism is one or more restaurants, cafes, food courts, a cottage industry that displays the particular culinary theme and relating to the locality of the region.

d. Tourism food is food-related tourist activities in tourism destinations such as eating at restaurants, buying local food products, and enjoy the unique experience of eating local production in certain regions

Gastronomy Tourism / Culinary refers to trips that are designed to enjoy the unique local production of food or drink.

\section{METHOD}

This study is a survey research conducted by combining quantitative and qualitative approaches. In achieving its 
objectives, the descriptive method is used to explain the phenomenon that is found within the study area. Study method is descriptive method to compile a database of gastronomy tourism destinations are conducted through desk study, field observation, focus group discussions (FGD), and assessed based on professional judgment. To devise a method or way of solving problems in approaching the goals, objectives, and goals of research activities need to consider the principles of research tailored to the characteristics of the convergence phenomenon and the existing problems.

The approach used in this study is a descriptive exploratory study. This type of research is chosen, because this study is a description of the data in tabular form and narrated in accordance facts on the ground. Secondary the data is more widely used to explore the possibility of developing local culinary seeded area. The use of the index value is the result of an agreement made at the date of FGD. FGD is a resource practitioners, academics, indigenous stakeholders, tourism agencies, and NGO representatives from counties and cities in the region of Ternate.

\section{RESULT}

\section{Profile of Ternate Tourism Destination}

Indonesia has tremendous potential tourism, one of which is the $77.27 \%$ Maluku sea areas, and $23.73 \%$ land area. The province has 395 large and small islands. Here you can enjoy a comprehensive travel both natural tourism, and cultural tourism which consists of historical, religious and gastronomical, as well as traditional spa. This region has a long history and influence the world.

History records that this area was once is the territory of the Sultanate Four Mountains in Maluku (Sultanate Moloko Kier Raha: Bacan islands, Sultanate Jailolo, Sultanate Tidore, and the Sultanate of Ternate). History also notes the Portuguese joint expedition landed in Ternate in 1511 in search of the Spice Islands. There is existence of history with many heritage such as;

a. Areas of Fort Orange, in which there is the Spice Museum that shows the influence of North Maluku spice in the world.

b. Museum Sultanate of Ternate, in which there are hairy crown adorned with 100 pieces i.e. gem stones Pearl, Diamond, Sapphire, Agate, emerald Mirah, Gold, Silver, Bronze and others. This crown is unique because the hair continue to grow and cut during Eid al-Adha with a special ceremony.

c. Sultanate of Ternate Mosque was established in 1648

d. The house of Alfred Russel Wallace, in which he wrote the letter "" The Letter from Ternate "in 1585.

e. Portuguese heritage historic fort was built as a defense clove such as Tolluko Fortress, Fortress Kastela, Fortress City of Promise (Fort Santo Pedro E Paulo).

f. The tomb of Sultan Mahmud Badarudin II Sultan of Palembang discharged into the city of Ternate in the reign of the Dutch East Indies,

g. The Catholic Church or the Church of St. Willibrord Stone is the only Catholic Church is on the island of Ternate.

h. Temple Thian Kiong Hou, not far from Fort Orange. This temple was established in 1657 and is the oldest in eastern Indonesia.

The author tries to find the appeal of traditional gastronomic tours in Ternate City. Based on the results obtained from the data that there is a gastronomic city is laden with traditional values and philosophies with their traditional ceremonies such as described on table 1 .

According inventory menu conducted in FGD "Preparing Potential Manuscript of Culinary and Spa" whisch has been held at the Hotel Majangan Kota Ternate (09/08/2016). This event was organized by the Ministry of Tourism Cultural Tourism Development Assistant Deputy of Cultural Tourism Departement with the speaker Dewi Turgarini, and Heni Pridia. Based on the survey, FGD, depth interviews, also literature in 2016, there is identified that Ternate city has a wealth of unique menu as a part of gastronomy tourism. There is totaling 194 menu, the which is 40 maincourse, two complete menus, 14, side dish or vegetable menu, Eight sauce, 45 dessert / cookies / cake / snacks, and five beverages as seen on table 2.

The stakeholders who attended composed of practitioners in the food industry, cultural and academia in Ternate. They agreed to declare five culinary icon that will be carried as a traditional food. The icons have value with history, tradition and philosophy, and use local raw material that should be known domestic and foreign tourists. The menu is on table 3.

TABLE I. THE TRADITION AND PHYLOSOPHY OF GASTRONOMY TOURISM IN TERNATE CITY

\begin{tabular}{|c|c|c|c|}
\hline No & Ceremony/Rites & Description & Menu \\
\hline 1 & $\begin{array}{lr}\text { Kololi Kie in } \\
\text { Legu } \\
\text { Festival }\end{array}$ & $\begin{array}{l}\text { Public ritual activities in Ternate to } \\
\text { cycle mountain Gamalama. This } \\
\text { ceremony performed while religious } \\
\text { visit some shrine that surround small } \\
\text { islands which have volcanoes }\end{array}$ & $\begin{array}{l}\text { Traditional food served such as; Sirikaya, Kobo (Ketupat Kerbau), Nanasi (Ketupat } \\
\text { Nanas), Nasi Jaha (Pali-Pali), Green bean porriage (Gule-gule Tamelo), Fish and } \\
\text { eggplant, Boboto / Boto-boto), Agi, (Sop Gulai), Steam Pulo, Grilled Fish, Whole } \\
\text { Chicken Stew, Asam Pedis (fish/chicken/meat), Fofoki (eggplant) Coconut Milk, Acar } \\
\text { Sambal Goreng, Boboto, Namo-Namo, Doga Rice, Cabu Tulang Fish, Yellow Rice Dada }\end{array}$ \\
\hline 2 & Saro-Saro & $\begin{array}{l}\text { Saro-Saro Wedding, is an activity of } \\
\text { prayer or request for the bride }\end{array}$ & $\begin{array}{l}\text { Traditional food served such as; Sirikaya, Kobo (Ketupat Kerbau), Nanasi (Ketupat } \\
\text { Nanas), Nasi Jaha (Pali-Pali), Green bean porriage (Gule-gule Tamelo), Fish and } \\
\text { eggplant, Boboto / Boto-boto), Agi, (Sop Gulai), Steam Pulo, Grilled Fish, Whole } \\
\text { Chicken Stew, Asam Pedis (fish/chicken/meat), Fofoki (eggplant) Coconut Milk, Acar } \\
\text { Sambal Goreng, Boboto, Namo-Namo, Doga Rice, Cabu Tulang Fish, Yellow Rice Dada, }\end{array}$ \\
\hline
\end{tabular}


Table I. Cont.

\begin{tabular}{lll}
\hline & $\begin{array}{l}\text { Saro-Saro Barber, is held at the time of } \\
\text { infants and children hair shaved. }\end{array}$ & $\begin{array}{l}\text { Menu yang dihidangkan adalah Sirikaya, Ketupat Kobo, Ketupat Nanasi , Raw material for } \\
\text { Joko Kaha (Fartago grass, a bottle of pure water, Pupulak Rice), Coconut water still in the } \\
\text { coconut fruit has been coloured. }\end{array}$ \\
\hline $\begin{array}{l}\text { Saro-Saro Khatam Qur'an, is the rite } \\
\text { after the kids finish reading /Khatam }\end{array}$ & $\begin{array}{l}\text { Served one ginger tree put inside a cup fill wit sugar, cane carved and decorated the form of } \\
\text { birds, airplanes assembled neatly in some form assemblies, Citrus Fruits neatly arranged in } \\
\text { some form assemblies, Pomegranate neatly arranged in some form of assemblies, Penang and } \\
\text { Sirih the declared at an assembly in several pieces assembled and Bars cigarettes are also } \\
\text { arranged in the form of several assemblies. }\end{array}$ \\
\hline 5 Lilian & $\begin{array}{l}\text { Lilian, is the activities carried outby } \\
\text { the mothers after hearing news of the } \\
\text { death of the community. }\end{array}$ & $\begin{array}{l}\text { The mothers came carrying groceries to donate to the makeshift funeral home as raw materials } \\
\text { and processed into consumption at the time of a prayer for the people who died for } 7 \text { days in a } \\
\text { row. }\end{array}$ \\
\hline
\end{tabular}

Source: Turgarini \& Pridia, 2016

\section{TABLE II. INVENTORY 121 MENU OF TERNATE CITY}

\begin{tabular}{|c|c|}
\hline Type of Menu & The Name of The Menu \\
\hline Main Course & $\begin{array}{l}\text { Agi, 2) Grilled Chicken, 3) Boboto, 4) Pupulak Rice, 5) Steam Batata, 6) Gatang (Crab) Walnut, 7) Fufu Fish, 8) Colo-Colo } \\
\text { Grilled Fish, 9) Rica Fish, 10) Ikan Woku, 11) Bobara Grilled Fish, 12) Asam Pedis Fish Soup, 13) Garupa Grilled Fish, 14) Carp } \\
\text { Grilled Fish, 15) Asar Fish, 16)Soru Fish Soup, 17) Snapper Fish Yellow Soup, 18) Raw Dabu-Dabu Grilled Fish, 19)Fried } \\
\text { Anvhovy Fish, 20) Tore/Roa Fish, Gohu Fish, 21) Ngafi Fish, 22) Garampati/Shredded Fish, 23) Galema, 24) Kasbi 25) } \\
\text { Kobo (Ketupat Kerbau), 26) Nanasi (Ketupat Nanas), 27) Jaha Rice, 28) Papeda, 29) Grilled Sagu, 30) SaguPupeda, 31) Soru, } \\
\text { 32) Sarondeh, 33) Steam Pulo, 34) Whole Chicken Stew, 35) Asam Pedis Fish Soup, 36) Asam Pedis Chicken Soup, Asam Pedis } \\
\text { Meat Soup, 37) Namo-Namo, 38) Doga Rice, 39) Boneless Fish, 40) Yellow Rice Dada, }\end{array}$ \\
\hline Complete Menu & Ikang Telur Yelow Rice, 2) Lontong Sayur \\
\hline Vegetable / Side Dishes & $\begin{array}{l}\text { Garo vegetables, 2) Lilin vegetables, 3) Fofoki (Eggplant) Coconut Milk Soup, 4) Gudangan, 5) Kusi, 6) Ulak-Ulak, 7) Rujak } \\
\text { Asam vegetables, 9) Kangkung vegetables, 10) Paku vegetables, 11) Ganemo, 12) Popare Isi Ikan 13) Ubi Pisang, 14) Ubu Talas }\end{array}$ \\
\hline Sauce & $\begin{array}{l}\text { Walnut Sauce, 2) Acar Fried Sauce, 3) Bakasang Sauce, 4) Roa/ Tore Fish Sauce, 5) Dabu-Dabu Sauce, 6) Dried Kasbi Sauce 7) } \\
\text { Tahi Minyak Sauce, 8) Anchovy Sauce }\end{array}$ \\
\hline $\begin{array}{l}\text { Dessert/Cookies/ } \\
\text { Cakes/Snack }\end{array}$ & $\begin{array}{l}\text { Abud, 2) Apang, 3)Apang Polote, 4)Amu Goreng, 5) Amo/Fried Sukun, 6) Angka Durian,7) Angka Walnuti, 8)Aneka Krepek, } \\
\text { 9)taro Batata, 10)Bagea Walnuut, 11)Balapis Seven Colour, 12)Green Bean Porriage (Gule-gule Tamelo) } \\
\text { 13)Cara Isi, 14) Cucur, 15) Coe Nagasari, 16) Coe Banana, 17) Cocoles, 18) Emping Durian Grain, 19) Halua, 20) Sagu } \\
\text { Cookies, 21) Kalombeng, 22) Corn Milu, } \\
\text { 22) Pulo Rice, 23) Lapis Chocolate, 24) Makron, 25) Pumpkin Coe, 26) Lamet, 27) Lapis Flag, 28) Lalampa, 29) Onde-Onde } \\
\text { (Kelepon), 30) Fried/Steam Mulu Bebe Banana, 31) Pupaco, 32) Palita, 33) Walnut Bread } \\
\text { 34) Coe, 35) Seka Walnut Bread, 36) Grilled Sambiki, 37) Sarikaya, 38) Sagu Loyang, 39) Sugong, 40) Surabi Cinkarong, 41) } \\
\text { Talam Sagu, 42) Milu Woku, 43) Panakuk/Lenggan-Lenggan, 44) Wajik, 45) Mud Banana }\end{array}$ \\
\hline Beverage & Guraka Water, 2) Pala Syrup, 3)Ternate Coffe, 4) Cinnamon Tea, 5) Guraka Cofee \\
\hline
\end{tabular}

The tourists while visiting the city of Ternate was able to enjoy the delights and experience a gastronomic tour is loaded with traditional values and philosophies that can be enjoyed from early morning until the late at night during the day. Travel tour was recommended when the implementation by the stakeholders present during the FGD, and also the time of the survey and interview by the author.

\section{TABLE III. FEATURES MENU TRADITIONAL GASTRONOMY OF} TERNATE CITY

\begin{tabular}{llll}
\hline No & Menu & \multicolumn{1}{c}{ Description } \\
\hline 1 & Papeda & $\begin{array}{l}\text { Papeda is porridge from sago flour with chewy texture is } \\
\text { the main carbohydrate source for the Ternate community }\end{array}$ \\
\hline 2 & $\begin{array}{l}\text { Gohu } \\
\text { Fish }\end{array}$ & $\begin{array}{l}\text { Gohu fish is raw fish menu is served in the community of } \\
\text { Ternate city made from tuna fish. }\end{array}$ \\
\hline 3 & $\begin{array}{l}\text { Fufu } \\
\text { Fish }\end{array}$ & $\begin{array}{l}\text { Fufu is smoked tuna fish typical of the city of Ternate, } \\
\text { which has a unique taste because it has a distinctive aroma } \\
\text { of wood. }\end{array}$ \\
\hline 4 & $\begin{array}{l}\text { Soru } \\
\text { Fish } \\
\text { Soup }\end{array}$ & $\begin{array}{l}\text { Soru Fish Soup is a menu prepared from fish snapper with } \\
\text { a concoction of fresh raw materials with the scent of lemon } \\
\text { and basil in the sauce. }\end{array}$ \\
\hline 5 & $\begin{array}{l}\text { Sayur } \\
\text { Garu }\end{array}$ & $\begin{array}{l}\text { Garu vegetable has a unique flavor because it consists of } \\
\text { a mixture of vegetables of heart banana, cassava leaves, } \\
\text { and the leaves of papaya has a unique taste and healthy. }\end{array}$ \\
\hline
\end{tabular}

Travel trips have value it is with history, tradition and philosophy, and use local raw material. The gastronomic tours in practice carried out by the tour operator in Ternate not be separated with other tours such as historical tours, religious tourism, shopping tourism and spa tourism. The comprehensive gastronomic tour as describe on table 4 .

There are also event that served many menu in this city such as in Legu Gam Festival, Selling of food in the Ramadhan month, Archipelago Culinary Festival and also cooking competition held by Woman Association (PKK) and Ternate city government as routine schedule can be an attraction for the tourist to visit.

\section{CONCLUSION}

Gastronomy tourism attraction in Ternate City has potential to develop as gastronomy city. The community still have skill to good cook especially with "Garden Food" and "Custom Food", also still practices many tradition held in their community such as Kololie Kie, Saro-Saro and Lilian, and still still served with custom food consist Sirikaya, Kobo (Ketupat Kerbau), Nanasi(Ketupat Nanas), Nasi Jaha(Pali-Pali), 
Bubur Kacang Hijau (Gule-gule Tamelo), Ikan dan Terong, Boboto / Boto-boto), Agi, (Sop Gulai), Makanan adat lainnya seperti : Pulo Kukus, ikan panggang, Ayam Utuh Semur, Asam Pedis (ikan/ayam/daging), Fofoki (Terong) utuh Santan, Acar Sambal Goreng, Boboto, Namo-Namo, Nasi Doga, Ikan Cabu Tulang, Nasi Kuning Dada. Also they still served rijstaffel menu namely "Garden Food", consist of Papeda, Ikan Gohu, Ikan Fufu, Ikan Kuah Soru, Sayur Garu,dabu-Dabu Roroba, Sagu Bakar, Pisang dan Ubi Rebus Santan and etc as a characteristic of the city center and / or region.

There is still exist the community which has cook skills such as Ternate City Woman Association and there are many traditional restaurants and / or chefs can service the tourist. The community still use of local raw materials traditional cuisine cooking; with local knowledge. Fstival Legu Gam, Saro-Saro Rites and competition has sexist but still need much effort to gain recognition nationally and internationally. Ternate city still has respect for the environment but need to promote of their main featured menu (Papeda, Gohu Fish,Fufu Fish, Fish Soru Fish and Garu Vegtables), and also another 194 otentisity menu still using sustainable local products. The city need more ability to maintain public appreciation, and there is a promotion of nutrition in educational institutions and inclusion of biodiversity conservation programs in cooking schools curricula.

This city also has a variety of tourist attraction gastronomic like Papeda, Grilled Sagu, Roal Tore Sauce home production, Also the unique cooking equipment in several traditional market combined with historical tours, religious tourism, nature tourism and shopping tour that will increase customer satisfaction and experience for the tourists who will not be forgotten.

\section{TABLE IV. ONE DAY GASTRONOMY TOUR IN TERNATE CITY}

\begin{tabular}{|c|c|c|c|}
\hline Time & Activity & Attraction & $\begin{array}{l}\text { Location/Contact } \\
\text { Person }\end{array}$ \\
\hline $\begin{array}{l}06.00- \\
07.00\end{array}$ & $\begin{array}{l}\text { Grilled Sagu } \\
\text { Process Making }\end{array}$ & Center of Grilled Sago manufacture in Kampung Bakar Tubo. & $\begin{array}{l}\text { Mrs.Nun Tubo Village } \\
\text { RT 08 RW 03 Contact } \\
\text { 085256913745. }\end{array}$ \\
\hline $\begin{array}{l}07.00- \\
08.00\end{array}$ & Breakfast & $\begin{array}{l}\text { Enjoy breakfast with a menu that is typical of the city of Ternate is Yellow Rice, who } \\
\text { served with the Mee Goreng, Fish Cooking Karing Kayu, with a choice of eggs, or } \\
\text { chicken. }\end{array}$ & $\begin{array}{l}\text { Rumah Makan Al } \\
\text { Hikmah at A.I.S. } \\
\text { Nasution Street, Middle } \\
\text { Ternate }\end{array}$ \\
\hline $\begin{array}{l}08.00- \\
10.00\end{array}$ & History of Spice & $\begin{array}{l}\text { Walking toward the tree of Cloves Afu, which is the world's oldest clove tree (1700). } \\
\text { During the trip tourists can see the efforts of residents with cloves and nutmeg crop and } \\
\text { enjoyed dringking nutmeg syrup. }\end{array}$ & $\begin{array}{l}\text { Air Tege Tege village } \\
\text { almost } 6 \text { kilometer } \\
\text { from central Ternate } \\
\text { city. }\end{array}$ \\
\hline $\begin{array}{l}10.00- \\
12.00\end{array}$ & $\begin{array}{l}\text { Gamalama / } \\
\text { Higienis Market }\end{array}$ & Visit to Gamalama Traditional Market, and Hygiene Market. & Centre of Ternate City \\
\hline $\begin{array}{l}11.00- \\
12.00\end{array}$ & Lunch & $\begin{array}{l}\text { Tourist can enjoy meal package "Garden Food" with fix rate Rp. 30.000. Garden food } \\
\text { consist Papeda, Ikan Gohu, Ikan Fufu, Ikan Kuah Soru, Sayur Garu,dabu-Dabu Roroba, } \\
\text { Sagu Bakar, Pisang dan Ubi Rebus Santan dan lainnya. }\end{array}$ & $\begin{array}{lr}\text { Popeda } & \text { Restaurant } \\
\text { Gamalama } & \text { Terminal } \\
\text { Pasar Baru } & \text { or Pasar } \\
\text { Higienis } & \end{array}$ \\
\hline & & $\begin{array}{l}\text { Lunch at a more representative with premium price. Here the tourist can enjoy special } \\
\text { and rare menu "Crab Walnuts". }\end{array}$ & $\begin{array}{l}\text { Florida Resto \& Café at } \\
\text { Ngade/Laguna Street }\end{array}$ \\
\hline $\begin{array}{l}12.00- \\
13.15 \\
\text { (Option }\end{array}$ & $\begin{array}{l}\text { Historical and } \\
\text { Religious } \\
\text { Tourism }\end{array}$ & $\begin{array}{l}\text { Palace and Mosque Sultan Ternate. Here tourists can see the beauty of the palace and } \\
\text { also visit the Mosque which was founded in the early 17th century (around 1606) during } \\
\text { the reign of Sultan Saidi Barakati. }\end{array}$ & $\begin{array}{l}\text { Sultan Khairun Street, } \\
\text { Soa Sio Village, North } \\
\text { Ternate District }\end{array}$ \\
\hline & & $\begin{array}{l}\text { Orange fort was established May 26, } 1607 \text { by Cornelis Matclief de Jonge. Spices } \\
\text { Museum located inside of Fort Orange. }\end{array}$ & Center of Ternate City \\
\hline $\begin{array}{l}12.45- \\
13.15 \\
\text { (Option } \\
\text { B) }\end{array}$ & $\begin{array}{l}\text { Historical } \\
\text { Tourism }\end{array}$ & $\begin{array}{l}\text { Tolukko fort, built by the Portuguese commander named Francisco Serao, in the year } \\
\text { 1540. The fort has an interesting architecture, also has a beautiful view of Ternate beach. }\end{array}$ & \\
\hline \multirow[t]{2}{*}{$\begin{array}{l}13.15- \\
15.30\end{array}$} & $\begin{array}{l}\text { Natural } \\
\text { Tourism }\end{array}$ & $\begin{array}{l}\text { Angus Stone, is nature tourism tourist can see petrified lava that show historical } \\
\text { geological process on this island. }\end{array}$ & \\
\hline & & $\begin{array}{l}\text { Tolire is a lake that has an myths attraction about the history of its formation, and also } \\
\text { has a wealth of fauna in their habitat such as of crocodiles in the lake. There is also a } \\
\text { unique snack that Mulu Bebe Fried, with Dabu-Dabu Sauce which can be enjoyed } \\
\text { alongside of the lake }\end{array}$ & $\begin{array}{l}\mathrm{km} \quad \text { from } \\
\text { Ternate city }\end{array}$ \\
\hline $\begin{array}{l}15.30- \\
16.00 \\
\text { (Option } \\
\text { A) }\end{array}$ & $\begin{array}{l}\text { Shopping } \\
\text { Tourism }\end{array}$ & $\begin{array}{l}\text { Ternate craftsmen woven fabric. This fabric has attractive colors and patterns, as well as } \\
\text { rare with a price range of Rp. } 2,000,000 \text { - up to Rp. } 3,000,000 \text {. Currently only three } \\
\text { craftsmen }\end{array}$ & $\begin{array}{lr}\text { Syamsudin } & \text { Head of } \\
\text { Tourism } & \text { Planning } \\
\text { Division } & \text { Ternate } \\
\text { Tourism Departement, } \\
\text { mobilephoe } \\
\text { 082195637667. }\end{array}$ \\
\hline $\begin{array}{l}15.30- \\
16.00 \\
\text { (Option } \\
\text { B) }\end{array}$ & & $\begin{array}{l}\text { Buying and learning making and packaging Ternate food product (Roa Sauce, four } \\
\text { variant of Shreded Fish, Garo Rica Fish (Original and Balado), Shredded Fish } 4 \text { variants } \\
\text { (original, berbagai rasa, spicy and dried ripe wood), Anchovy Sauce, Dried Shrimp } \\
\text { Sauce, Anchovy Crisp, Taro Chips.Mrs }\end{array}$ & $\begin{array}{l}\text { Mrs. Siti Sulastri owner } \\
\text { of Fala Tanawan } \\
\text { Industry. Location back } \\
\text { of Askes Office RT } \\
\text { 14/RW } 15 \text { Maliaro } \\
\text { Village, Middle Ternate } \\
\text { District }\end{array}$ \\
\hline
\end{tabular}


Table IV. Cont.

\begin{tabular}{|c|c|c|c|}
\hline $\begin{array}{l}16.00- \\
17.30\end{array}$ & $\begin{array}{lr}\text { Fufu } & \text { Smoked } \\
\text { Fish } & \text { Making } \\
\text { Process } & \end{array}$ & $\begin{array}{l}\text { Seeing the manufacturing process and buy Smoke Fish Fufu newly made at 15:00 until } \\
\text { 16:00 }\end{array}$ & $\begin{array}{l}\text { Mrs. Zenab/ Mrs. Anna } \\
\text { Mutiara Street RT } 7 \\
\text { Sangaji Village }\end{array}$ \\
\hline $\begin{array}{l}17.30- \\
19.00\end{array}$ & Back to Hotel & Bath and Rest & Personal Hotel \\
\hline \multirow{3}{*}{$\begin{array}{l}19.00- \\
20.00\end{array}$} & \multirow[t]{3}{*}{ Dinner } & Enjoying beach and can select many Ternate menu, and Indonesian archipelago menu. & Nukila Beach \\
\hline & & Enjoying fried Banana Mulu Bebe and Guraka Beverage in the coast. & Falajawa Beach \\
\hline & & $\begin{array}{l}\text { Enjoying various fish from the deep sea. The sensation of grilled fish processed starting } \\
\text { with fish buyers choose their own desire of diverse and unique fresh fish does not exist in } \\
\text { other regions. }\end{array}$ & $\begin{array}{ll}\text { Gamalama } & \text { Terminal } \\
\text { and Market } & \end{array}$ \\
\hline $20.00-$ & \multirow{2}{*}{$\begin{array}{l}\text { Shopping } \\
\text { Tourism }\end{array}$} & Here tourist can buy souvenirs of various foods, drinks, crafts, and also typical batik & \\
\hline 21.30 & & patterned cloves and nutmeg. & $\begin{array}{l}\text { Supermarket, Falajawa } \\
\text { Beach. }\end{array}$ \\
\hline $\begin{array}{l}21.30 . \\
22.30\end{array}$ & Spa Tourism & $\begin{array}{l}\text { After enjoying the beauty of this city all day, tourist can enjoy a traditional massage } \\
\text { typical of the city of Ternate conducted by Biang. }\end{array}$ & Personal Hotel \\
\hline
\end{tabular}

\section{REFERENCES}

Anas. (2014). Mengemas Kebudayaan dan Pariwisata Menjadi Potensi Unggulan di Kota Ternate. (ppt). Ternate. Cultural and Tourism Departement of Ternate City.

Busranto Latif Doa. 2010. Kololi Kie Tradisi Ritual Adat Mengelilingi Ternate Sambil Ziarah Beberapa Makam Keramat. https://ternate.wordpress.com/2010/02/23/kololi-kietradisi-ritual-adat-mengelilingi-pulau-ternate-sambilziarah-beberapa-makam-keramat/. Retrieved September 2015

Disbudpar Kota Ternate. 2013. Oranje. http://disbudparkotaternate.com/Page\%20Oranje/oranje.html. Retrieved 11 Juli 2015.

Hall, C. M., \& Mitchell, R. (2001). Wine and Food Tourism. In N. Douglas, N. Douglas \& R. Derrett (Eds.), Special Interest Tourism. New York: Wiley.

Inskeep, E. (1991). Tourism planning: an integrated and sustainable development approach. New York: Van Nostrand Reinhold.

Kemenpar (Kementerian Pariwisata). (2015). Pengembangan destinasi wisata melalui pelestarian makanan tradisional. Paper presented in National Gastronomy Dialog held by Academy Gastronomy of Indonesia on 23-24 November 2015, Jakarta.

Kementrian Pariwisata, Pos dan Telekomunikasi. 1992. Spanyol dan Maluku Galleon-Galleon Mengelilingi Dunia. Jakarta.
Ramerini, Marco 'Le Fortezze Spagnole nell'Isola di Tidore 1521-1663” Firenze, 2008.

Soeroso, A. (2014). Foodscape, Cultural Landscape dan Arkeologi: Sebuah Upaya Pelestarian Cagar Budaya dan Pembangunan Ekonomi Indonesia. Paper presented in Arceology Expert Association of Indoneisa Congress on 25 Juny 2014 in Fort Vredeburg, Yogyakarta.

. (2014b). Quo Vadis Gastronomi Indonesia. Paper presented as introduction on FGD Akademi Gastronomy of Indonesia on 25 April 2014 in Founding Father's House, South Jakarta.

Symons, M. (1999). Gastronomic authenticity and the sense of place. Paper presented at the 9th Australian Tourism and Hospitality Research Conference for Australian University Tourism and Hospitality Education.

Turgarini, D. (2016). Ternate Kota Wisata gastronomi Indonesia. $\quad \mathrm{http}: / /$ mik.upi.edu/ternate-kota-wisatagastronomi-indonesia/. Retrieved 19 Oktober 2016.

Turgarini, D and Pridia, H. (2016). Laporan Akhir Profil Wisata Kuliner Kota Ternate. Jakarta. Deputy Assistant of Cultural Tourism Development Ministry Tourism of Indonesia.

UNWTO. (2013). UNWTO Tourism Highlight 2010 Edition. New York: UNWTO Publications Department.

UNESCO. (2015). UNESCO Creative Cities. http://en.unesco.org/creative-cities/home

. (2015). Tourism Highlights: 2015 Edition. Geneva: the World Economic Forum. 